OPEN ACCESS

Edited by:

Saddam Hussain,

University of Agriculture, Pakistan

Reviewed by:

Shankar Lal Jat,

Indian Council of Agricultural Research

(ICAR), India

Jianbin Zhou,

Northwest $A$ and $F$ University, China

*Correspondence:

Benedicta Essel

esselbenedicta@yahoo.com

Specialty section: This article was submitted to Plant-Soil Interactions, a section of the journal

Frontiers in Soil Science

Received: 23 December 2020 Accepted: 01 March 2021 Published: 06 April 2021

Citation:

Essel B, Abaidoo RC, Opoku A and Ewusi-Mensah N (2021) Mechanisms

Underlying Nutrient Interaction of

Compost and Mineral Fertilizer

Application in Maize (Zea mays L.)

Cropping System in Ghana.

Front. Soil Sci. 1:630851

doi: 10.3389/fsoil.2021.630851

\section{Mechanisms Underlying Nutrient Interaction of Compost and Mineral Fertilizer Application in Maize (Zea mays L.) Cropping System in Ghana}

\author{
Benedicta Essel ${ }^{1,2 *}$, Robert Clement Abaidoo ${ }^{3,4}$, Andrews Opoku ${ }^{1}$ and \\ Nana Ewusi-Mensah ${ }^{1}$
}

${ }^{1}$ Department of Crop and Soil Sciences, Faculty of Agriculture, Kwame Nkrumah University of Science and Technology, Kumasi, Ghana, ${ }^{2}$ Soil Fertility and Plant Nutrition Division, Council for Scientific and Industrial Research (CSIR)-Soil Research Institute, Kumasi, Ghana, ${ }^{3}$ Department of Theoretical and Applied Biology, Kwame Nkrumah University of Science and Technology, Kumasi, Ghana, ${ }^{4}$ Soil Microbiology Section, International Institute of Tropical Agriculture, Ibadan, Nigeria

Mechanisms underlying interactive effects of nutrient inputs on crop yields are poorly understood especially throughout sub-Saharan Africa. This research thus sought to evaluate the possible mechanisms causing the interaction effects from compost and mineral fertilizer and quantify the relative contribution(s) of the mechanisms to added benefits in grain yield. The research involved a 3-year field experiment followed by a greenhouse incubation study. Both field and incubation experiments were $5 \times 5$ factorial arranged in Randomized Complete Block Design and Completely Randomized Design (CRD) with three replications, respectively. The factors considered were five levels of mineral fertilizer $\left(0,25,50,75\right.$, and $100 \%$ of $\left.90: 60: 70 \mathrm{~kg} \mathrm{ha}^{-1} \mathrm{~N}: \mathrm{P}_{2} \mathrm{O}_{5}: \mathrm{K}_{2} \mathrm{O}\right)$ and compost $\left(0,25,50,75\right.$, and $100 \%$ of $5 \mathrm{Mg} \mathrm{ha}^{-1}$ compost). The mechanisms evaluated were nutrient synchrony, priming, general soil fertility improvement (GFI), and balanced ratio of nutrients. The conjoint application of compost and mineral fertilizer significantly $(p$ $\leq 0.05$ ) influenced grain yields of maize, with $50 \%_{\mathrm{RR}} \mathrm{MF}+100 \% \mathrm{RR}_{\mathrm{R}} \mathrm{Co}$ producing the highest average grain yields in 2015 and 2017 with relative average grain yield increases of 167 and $98 \%$ over the control (no application), respectively. The conjoint application of nutrients resulted in synergistic and antagonistic interactions. Synergistic interactions were observed in the first 2 years of the study, followed by antagonistic interactions in the third year. Three principal components cumulatively explained $86 \%$ of the variation among the mechanisms. The mechanisms which contributed most to the added benefits were priming effect, balanced nutrient ratio, and nutrient synchrony.

Keywords: added benefit, balanced ratio of nutrients, incubation, mechanism, nutrient synchrony, nutrient priming effect

\section{INTRODUCTION}

Soil fertility depletion in smallholder farmers' fields is a major biophysical cause for the declining rate of crop production in most sub-Saharan African countries (1). This has resulted in low per capita food production (2) with reduced crop yields amounting to over US\$ 4 billion annually (3). Therefore, adding nutrient inputs in the form of organic and mineral fertilizers will improve soil fertility and increase crop yields (4). 
Roy et al. (5) opined that, in a highly developed agriculture system, large increases in yield potential would most likely result from consequent interaction effects of nutrient inputs. Nutrient interaction in crops is a major factor influencing the yields of annual crops (6). They occur in crop plants when the supply of one nutrient influences the absorption and utilization of other nutrients $(6,7)$.

Extra crop yields result from the combined application of nutrient inputs (8). This produces added benefits resulting in extra crop yields and improved soil fertility, relative to the sum of the responses in sole nutrient input (8). Few studies quantifying added benefits in Africa were those of Nhamo (9) with values between 118 and $663 \mathrm{~kg} \mathrm{ha}^{-1}$ maize grains, and Mucheru et al. (10) who also recorded values ranging from -250 to $550 \mathrm{~kg} \mathrm{ha}^{-1}$ maize grains. Furthermore, Iqbal et al. (11) reported that, combining compost with mineral fertilizer significantly $(p \leq 0.05)$ increased grain yield of maize and other yield indicators than the sole application of compost. Though, the soils used by the aforementioned authors were deficient in $\mathrm{N}$ and organic carbon, the observed grain yield range $(2.35-7.55 \mathrm{Mg}$ $\mathrm{ha}^{-1}$ ) was higher than previously reported maize yields from different studies in Pakistan, confirming the beneficial effects of compost when supplemented with mineral fertilizer. Togun and Akanbi (12) also reported that, the use of compost either alone or in combination with mineral fertilizer was more beneficial than the control. Furthermore, Chivenge et al. (13) affirmed the importance of integrated nutrient management (INM), as the combined application of organic resources and mineral fertilizers can result in grain yield increases of up to $400 \%$ over the control.

There are divergent research opinions on nutrient interaction due to the fact that the mechanisms involved are not wellunderstood. In Ghana, Yeboah et al. (14) reported that, INM gave higher maize grain yield relative to the sole application of organic or mineral fertilizers. Brempong et al. (15) also observed that, using 60:40:40 $\mathrm{kg} \mathrm{ha}^{-1} \mathrm{NPK}+5 \mathrm{Mg} \mathrm{ha}^{-1}$ cattle manure produced the highest grain yield of $4,678 \mathrm{~kg} \mathrm{ha}^{-1}$. Added benefits in grain yield of -68 to 470 and -514 to $684 \mathrm{~kg} \mathrm{ha}^{-1}$ were reported by Opoku (16) at Nyankpala and Sarauniya, respectively. However, without a clear understanding of the mechanisms underlying enhanced crop yields resulting from synergistic interactions of the combined application of mineral fertilizer and organic inputs, one can underestimate the occurrence of antagonistic interaction (17).

The positive effects of nutrient amendments on crop yields are attributed to different, not mutually exclusive mechanisms (18). There is therefore an urgent need to generate a more detailed understanding into the potential mechanisms causing added benefits/disadvantages from the combined application of organic amendments and mineral fertilizers (8), and quantify the contribution of these mechanisms to added benefits in grain yields. Mechanisms for added benefits in grain yields have been attributed to improved nutrient synchrony between crop nutrient demand and soil nutrient release (19, 20); priming (21, 22); improvement in soil quality indicators $(6,23,24)$; preferential transport of nutrients (6); balanced nutrient ratios of 7:1 Ca: $\mathrm{Mg}$, 1:1 K:Mg (25), 10:1 P:Zn, 2:1 Fe:Mn (26), etc. Badu (27), ranked the key mechanisms resulting in synergistic interactions in order of their relative contributions as improved nitrogen synchrony $>$ priming effect $>$ general fertility improvement. Knowledge of the mechanism causing nutrient interactions will enhance the adoption of soil management practices that will contribute to improvement in crop productivity and soil fertility.

Based on the research hypothesis that added benefits resulting from the conjoint application of compost and mineral fertilizer to maize is driven by underlying mechanisms, this study sought to achieve the following objectives: (i) evaluate the effect of combined application of mineral fertilizer and the compost on soil fertility and maize yield, (ii) to quantify the added benefits resulting from the conjoint application and mineral fertilizer to maize, and (iii) to evaluate mechanisms underlying the interaction effects resulting from the conjoint application and mineral fertilizer to maize.

\section{MATERIALS AND METHODS Description of the Study Site}

A 3-year field experiment was conducted at the research field of the Kwame Nkrumah University of Science and Technology (KNUST) located on latitude $6^{\circ} 40^{\prime} 59.364^{\prime \prime} \mathrm{N}$ and longitude $1^{\circ} 33^{\prime} 3.618^{\prime \prime} \mathrm{W}$ at an elevation of $287 \mathrm{~m}$ in the semi-deciduous forest agro-ecological zone of Ghana. The research site has a bimodal rainfall pattern with peaks in June and October. The beginning of the major rainy season is from March to July, followed by a dry spell in August, while the minor season spans from September to November. The mean annual rainfall is $1,500 \mathrm{~mm}$, relative humidity is $67 \%$, and mean temperature ranges from 21 to $31^{\circ} \mathrm{C}$. Soil of the study site has been classified as Ferric Acrisol and belongs to the Kumasi series, developed over a deeply weathered granite (28).

Characterization of the soil at the experimental site, prior to field establishment indicated that the soil was loamy sand with a low bulk density of $1.13 \mathrm{Mg} \mathrm{m}^{-3}$ (Table 1 ). The soil $\mathrm{pH}$ was slightly acidic. The total organic carbon, nitrogen and available $\mathrm{P}$ contents recorded were very low and the concentration of exchangeable cations was very low to moderate. The ratings were done according to the classification of Landon (29). The nutrient ratios of the soil were unbalanced (Table 1). The overall fertility of the soil at the study area was classified as low.

\section{Treatments and Experimental Design}

The field experiment was a $5 \times 5$ factorial arranged in Randomized Complete Block Design (RCBD) with three replications for each treatment. The factors considered were five levels of mineral fertilizer $(0,25,50,75$, and $100 \%$ of $90: 60: 70 \mathrm{~kg}$ $\left.\mathrm{ha}^{-1} \mathrm{~N}: \mathrm{P}_{2} \mathrm{O}_{5}: \mathrm{K}_{2} \mathrm{O}\right)$ and five levels of compost $(0,25,50,75$, and $100 \%$ of $5 \mathrm{Mg} \mathrm{ha}^{-1}$ of compost), giving a total of 25 treatment combinations. The compost used for this study was prepared from cattle manure, palm kernel cake, rock phosphate, and cocoa pod husk. The rationale behind the use of these materials and the compost preparation method are described in Essel (30). The average $\mathrm{N}, \mathrm{P}, \mathrm{K}$, and $\mathrm{C}$ contents of the applied compost over the three cropping years were $1.40 \pm 0.26,1.87 \pm 1.39,1.41$ $\pm 1.23,23.70 \pm 1.59 \%$, respectively. The average C:N ratio and plant residue quality index of the compost were $17.83 \pm 3.79$ 
TABLE 1 | Initial physico-chemical properties of the soil at the experimental site $(0-15 \mathrm{~cm})$.

\begin{tabular}{|c|c|}
\hline Soil property & Value \\
\hline \multicolumn{2}{|l|}{ PHYSICAL PROPERTIES } \\
\hline Sand (\%) & 81.76 \\
\hline Silt (\%) & 7.40 \\
\hline Clay (\%) & 10.84 \\
\hline Texture & Loamy sand \\
\hline Bulk density ( $\mathrm{Mg} \mathrm{m}^{-3}$ ) & 1.13 \\
\hline Soil moisture content (\%) & 8.12 \\
\hline \multicolumn{2}{|l|}{ CHEMICAL PROPERTIES } \\
\hline Soil pH $\left(1: 1, \mathrm{H}_{2} \mathrm{O}\right)$ & 6.70 \\
\hline Soil organic carbon (\%) & 1.24 \\
\hline Available $\mathrm{P}\left(\mathrm{mg} \mathrm{kg}^{-1}\right)$ & 4.02 \\
\hline Mineral $\mathrm{N}\left(\mathrm{mg} \mathrm{kg}^{-1}\right)$ & 53.42 \\
\hline \multicolumn{2}{|l|}{ Exchangeable bases $\left[\mathrm{cmol}_{(+)} \mathrm{kg}^{-1}\right]$} \\
\hline $\mathrm{Ca}^{2+}$ & 2.20 \\
\hline $\mathrm{Mg}^{2+}$ & 1.20 \\
\hline $\mathrm{K}^{+}$ & 0.76 \\
\hline $\mathrm{Na}^{+}$ & 0.08 \\
\hline Exchangeable acidity $\left(\mathrm{Al}^{3+}+\mathrm{H}^{+}\right)\left[\mathrm{cmol}_{(+)} \mathrm{kg}^{-1}\right]$ & 1.07 \\
\hline ECEC $\left[\mathrm{cmol}_{(+)} \mathrm{kg}^{-1}\right]$ & 4.24 \\
\hline \multicolumn{2}{|l|}{ Micronutrients (mg kg ${ }^{-1}$ ) } \\
\hline Zinc & 1.15 \\
\hline Iron & 20.48 \\
\hline Manganese & 18.68 \\
\hline \multicolumn{2}{|l|}{ NUTRIENT RATIOS } \\
\hline Ca:Mg & $1.8: 1$ \\
\hline $\mathrm{K}: \mathrm{Mg}$ & $0.6: 1$ \\
\hline$P: Z n$ & $3.5: 1$ \\
\hline Fe:Mn & $1.1: 1$ \\
\hline
\end{tabular}

ECEC, Effective cation exchange capacity.

and $6.60 \pm 1.40$, respectively. The fertilizers applied were urea, triple superphosphate, and muriate of potash to supply $\mathrm{N}, \mathrm{P}$, and $\mathrm{K}$, respectively. Farmers' preferred maize variety in the study area, Omankwa, an early-maturing (90-95 days) was used as the test crop.

\section{Crop Management Practices}

The experimental site was disc plowed and harrowed to a depth of $15 \mathrm{~cm}$ prior to the first cropping. Maize seeds were sown at a spacing of $75 \times 40 \mathrm{~cm}$ at two seeds hill ${ }^{-1}$. Application of compost and mineral fertilizer was done, 2 weeks after sowing (2WAS). Application of all inorganic fertilizers were done at approximately $10 \mathrm{~cm}$ to the side of each plant by band placement at 2WAS. Urea was however, applied in two splits with $75 \%$ applied 2WAS and 25\% at 5WAS. Hoeing was done on the treatment plots as and when necessary. At physiological maturity, maize plants within the three central rows of each plot were harvested for grain yield determination. Maize grain was dried to $15 \%$ moisture content after harvesting using an oven at a temperature of $70^{\circ} \mathrm{C}$ for $48 \mathrm{~h}$.

\section{Added Benefit in Maize Grain Yields}

Added benefit in grain yield from the combined application of compost and mineral fertilizer, over the sole application of either compost or mineral fertilizer was calculated as,

$$
\begin{aligned}
& \text { Added benefit }=Y_{\text {comb }}-\left(Y_{f e r t}-Y_{c t r l}\right)-\left(Y_{\text {comp }}-Y_{c t r l}\right) \\
& -Y_{c t r l} \text { [Vanlauwe et al. (19)] }
\end{aligned}
$$

where: $\mathrm{Y}_{\mathrm{comb}}$, mean grain yields in treatments with combined application of compost and mineral fertilizer; $Y_{\text {fert }}$, mean grain yields in the treatments with sole application of mineral fertilizer; $\mathrm{Y}_{\mathrm{ctrl}}$, mean grain yields in the control treatment; and $\mathrm{Y}_{\text {comp }}$, mean grain yield in treatments with sole compost application.

\section{Incubation Experiment}

The soil used for the incubation experiment was sampled from a depth of $0-15 \mathrm{~cm}$ in the alleys of the experimental field previously used for maize cropping. The mechanisms evaluated were improved nutrient synchrony, priming effect, general soil fertility improvement (GFI), and balanced ratio of nutrients. The 25 treatments used in the field experiment were incubated under greenhouse condition and arranged in a $5 \times 5$ Factorial Completely Randomized Design (CRD) replicated three times.

A total of 225 plastic pots were each filled with $492 \mathrm{~g}$ soil for the incubation experiment. The quantity of soil used for filling each plastic container was calculated on a dry mass basis in relation to the volume of the containers and the bulk density of the soil before sampling the soil for the incubation experiment. The volume of the plastic containers used was $1 \mathrm{~L}$ and the bulk density of the soil before sampling was $1.13 \mathrm{Mg}$ $\mathrm{m}^{-3}$. The compost and mineral fertilizer were then weighed and added to each plastic container based on the treatment description and the mass of soil in the plastic pots. Distilled water $(90 \mathrm{ml})$ was then added to each plastic container to attain $28 \%$ moisture content at field capacity. The soil in each pot was then mixed thoroughly with water and the appropriate soil amendment using a stirrer. Each pot was finally covered with a gas permeable parafilm to reduce moisture loss and carefully placed in metal grids at the greenhouse. Moisture content of the different pots were monitored and adjusted periodically in the course of the incubation experiment. The temperature in the greenhouse ranged from 25 to $33^{\circ} \mathrm{C}$, whereas the relative humidity was $50-70 \%$.

For improved nutrient synchrony, nitrogen synchrony index (NSI) and phosphorus synchrony index (PSI) were computed at 14,42 , and 84 days after incubation (DAI) to determine the synchrony between nutrient release from the treatments and the crop nutrient requirement of maize. Before the estimation of NSI, leaching losses were accounted for, by adapting the N-leaching regression model by DeWilligen (31):

$$
\begin{aligned}
\mathrm{N} \text { leaching } & =21.37+(\mathrm{P} / \mathrm{C} \times \mathrm{L}) \times(0.0037 \times \mathrm{NF} \\
& +0.000060 \times \mathrm{OC}-0.00362 \times \mathrm{NU})
\end{aligned}
$$

where $\mathrm{P}$, annual precipitation; C, \% clay content; L, rooting depth; $\mathrm{F}, \mathrm{N}$ content of mineral fertilizer and compost; OC, organic carbon content of the soil; and NU, N uptake by the crop. The soil mineral nitrogen and available phosphorus estimated at each 
sampling time were transformed into unit-less values with the aid of a linear scoring function on a scale of 1-10. The transformed values were then used to estimate NSI and PSI as shown in Equations 3 and 4.

$$
\begin{aligned}
& \text { NSI }=\frac{\left(\sum_{t=i}^{n} N_{i}\right)}{n} \\
& \text { PSI }=\frac{\left(\sum_{t=i}^{n} P_{i}\right)}{n}
\end{aligned}
$$

where $\mathrm{Ni}$, score value for nitrogen synchrony; $\mathrm{Pi}$, score value for phosphorus synchrony; and $t=$ number of sampling times.

Nutrient priming effect was determined at 14, 42, and 84 DAI by adopting Equation 5 below by Kuzyakov et al. (21).

$$
\begin{aligned}
\mathrm{PE} & =N \operatorname{release}_{(\mathrm{comb})}-\left(N \operatorname{release}_{(\mathrm{fert})}-N \operatorname{release}_{(\mathrm{ctrl})}\right) \\
& -\left(\operatorname{Nrelease}_{(\mathrm{comp})}-N \operatorname{release}_{(\mathrm{ctrl})}\right)-N \operatorname{release}_{(\mathrm{ctrl})}
\end{aligned}
$$

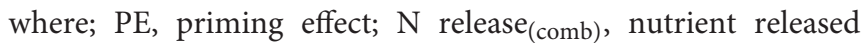
from combined application of compost and mineral fertilizer; $\mathrm{N}$ release ${ }_{(\text {fert) }}$, nutrient released from sole fertilizer treatment; $\mathrm{N}$ release $_{(\text {comp })}$, nutrient released from sole compost treatment; and $\mathrm{N}$ release $(\mathrm{ctrl})$, nutrient released from the control.

General fertility improvement mechanism was assessed by determining soil organic carbon, total $\mathrm{N}$, available $\mathrm{P}$, and exchangeable $\mathrm{K}$ of the treatments at the start (Day 0) and end of incubation (84 DAI). For the balanced ratio mechanism, Ca:Mg; K:Mg; P:Zn; and Fe:Mn ratios were determined at Day 0 and at 84 DAI.

\section{Data Collection and Laboratory Analyses}

Prior to the setting up of the greenhouse incubation experiment, particle size distribution, moisture content, $\mathrm{pH}$, organic carbon, and micronutrients ( $\mathrm{Zn}, \mathrm{Fe}$, and $\mathrm{Mn}$ ) were determined by the methods described by Motsara and Roy (32). Total N, available P, exchangeable $\mathrm{K}, \mathrm{Ca}$, and $\mathrm{Mg}$ were also determined using standard protocols by Motsara and Roy (32). The compost used was also characterized for total C, N, P, K, Ca, Mg, Na, Zn, and Fe using standard protocols as described by Motsara and Roy (32).

\section{Statistical Analyses}

Data collected during the experiment were subjected to Analysis of Variance (ANOVA) using General Statistical Software Package (33). Data on maize grain yield during the field experiment was analyzed using a two-way ANOVA with randomized blocks procedure. For the greenhouse incubation experiment, data collected were subjected to two-way ANOVA with CRD Principal Component Analysis (PCA) in JMP Pro 13.0.0 (34) was used to quantify the relative contributions of the mechanisms. Principal components were identified as the variables having Eigen value $>1$ and a cumulative percentage variance of $\geq 80 \%$ (35). The

\begin{tabular}{|c|c|c|c|c|}
\hline \multicolumn{2}{|l|}{ Nutrient input } & 2015 & 2016 & 2017 \\
\hline $\begin{array}{l}\text { Mineral } \\
\text { fertilizer (\%RR) }\end{array}$ & $\begin{array}{c}\text { Compost } \\
\text { (\%RR) }\end{array}$ & \multicolumn{3}{|c|}{ Grain yield $\left(\mathrm{Mg} \mathrm{ha}^{-1}\right)$} \\
\hline \multirow[t]{5}{*}{0} & 0 & 1.35 & 2.99 & 2.77 \\
\hline & 25 & 1.50 & 2.23 & 2.67 \\
\hline & 50 & 1.19 & 3.35 & 3.98 \\
\hline & 75 & 1.76 & 4.85 & 3.96 \\
\hline & 100 & 1.56 & 4.15 & 4.76 \\
\hline \multirow[t]{5}{*}{25} & 0 & 3.08 & 3.12 & 3.97 \\
\hline & 25 & 1.97 & 2.73 & 3.62 \\
\hline & 50 & 2.55 & 4.29 & 4.15 \\
\hline & 75 & 3.47 & 3.78 & 3.52 \\
\hline & 100 & 2.47 & 3.63 & 4.47 \\
\hline \multirow[t]{5}{*}{50} & 0 & 2.99 & 2.80 & 3.91 \\
\hline & 25 & 1.66 & 4.24 & 3.61 \\
\hline & 50 & 3.33 & 3.54 & 4.52 \\
\hline & 75 & 3.20 & 2.63 & 4.08 \\
\hline & 100 & 3.53 & 3.89 & 5.48 \\
\hline \multirow[t]{5}{*}{75} & 0 & 2.40 & 3.44 & 4.04 \\
\hline & 25 & 2.63 & 2.64 & 4.84 \\
\hline & 50 & 3.00 & 3.56 & 3.98 \\
\hline & 75 & 3.14 & 5.68 & 4.66 \\
\hline & 100 & 2.96 & 4.40 & 5.13 \\
\hline \multirow[t]{5}{*}{100} & 0 & 2.23 & 3.31 & 3.77 \\
\hline & 25 & 2.83 & 4.87 & 3.42 \\
\hline & 50 & 2.42 & 3.40 & 3.49 \\
\hline & 75 & 3.44 & 3.24 & 4.12 \\
\hline & 100 & 3.34 & 5.12 & 3.41 \\
\hline Fpr. (MF × Co) & & $<0.001$ & $<0.001$ & $<0.001$ \\
\hline LSD(0.05) & & 0.58 & 0.51 & 0.63 \\
\hline CV (\%) & & 13.80 & 8.40 & 9.50 \\
\hline Fpr. (MF) & & $<0.001$ & $<0.001$ & $<0.001$ \\
\hline Fpr. (Co) & & $<0.001$ & $<0.001$ & $<0.001$ \\
\hline
\end{tabular}
variables with absolute loadings of $\geq 0.50$ were identified as the significant variables contributing to each principal component.
TABLE 2 | Effect of compost and mineral fertilizer application on maize grain yield.

Values are means of three replicates. \%RR MF, percentage recommended rate of mineral fertilizer; \%RR Co, percentage recommended rate of compost; $L S D$, least significant difference; RYI, relative yield increase.

\section{RESULTS}

\section{Effects of Conjoint Application of Compost and Mineral Fertilizer on Grain Yield of Maize, Soil Chemical Properties and Added Benefits in Grain Yield}

Generally, the conjoint use of compost and mineral fertilizer significantly ( $p \leq 0.001)$ increased grain yield throughout the 3 -year experimental period (Table 2). On average, maize grain yields observed during the 2016 and 2017 major cropping seasons were 43 and 56\%, respectively, superior to the yield recorded in 2015. The application of $50 \%{ }_{R R} M F+100 \%_{R R}$ Co produced the highest average grain yields with relative increases of 167 and $98 \%$ over the control in 2015 and 2017, respectively. However, in 
TABLE 3 | Effect of compost and mineral fertilizer application on soil chemical properties at the end of 3 years cropping.

\begin{tabular}{|c|c|c|c|c|c|}
\hline \multirow{2}{*}{$\begin{array}{l}\text { Nutrient input } \\
\text { Mineral fertilizer } \\
\text { (\%RR) }\end{array}$} & \multirow[b]{2}{*}{$\begin{array}{c}\text { Compost } \\
\text { (\%RR) }\end{array}$} & \multicolumn{4}{|c|}{ Soil chemical properties } \\
\hline & & $\begin{array}{c}\text { Organic C } \\
(\%)\end{array}$ & $\begin{array}{c}\text { Total N } \\
(\%)\end{array}$ & $\begin{array}{c}\text { Av. P } \\
\left(\mathrm{mgkg}^{-1}\right)\end{array}$ & $\begin{array}{c}\text { Exch. K } \\
{\left[\mathrm{cmol}_{(+)} \mathbf{k g}^{-1}\right]}\end{array}$ \\
\hline \multirow[t]{5}{*}{0} & 0 & 1.0 & 0.08 & 6.3 & 0.12 \\
\hline & 25 & 1.1 & 0.08 & 7.6 & 0.12 \\
\hline & 50 & 1.0 & 0.09 & 7.7 & 0.15 \\
\hline & 75 & 1.1 & 0.09 & 8.2 & 0.32 \\
\hline & 100 & 1.1 & 0.08 & 7.4 & 0.21 \\
\hline \multirow[t]{5}{*}{25} & 0 & 0.9 & 0.11 & 8.1 & 0.13 \\
\hline & 25 & 1.1 & 0.09 & 7.9 & 0.12 \\
\hline & 50 & 1.2 & 0.09 & 9.5 & 0.14 \\
\hline & 75 & 1.1 & 0.08 & 9.2 & 0.23 \\
\hline & 100 & 0.9 & 0.08 & 7.4 & 0.14 \\
\hline \multirow[t]{5}{*}{50} & 0 & 1.0 & 0.08 & 7.5 & 0.10 \\
\hline & 25 & 1.4 & 0.11 & 8.9 & 0.18 \\
\hline & 50 & 1.1 & 0.09 & 10.1 & 0.13 \\
\hline & 75 & 1.1 & 0.09 & 8.6 & 0.13 \\
\hline & 100 & 1.1 & 0.08 & 18.3 & 0.14 \\
\hline \multirow[t]{5}{*}{75} & 0 & 0.9 & 0.08 & 6.6 & 0.13 \\
\hline & 25 & 1.1 & 0.11 & 11.8 & 0.24 \\
\hline & 50 & 1.2 & 0.08 & 9.3 & 0.13 \\
\hline & 75 & 1.0 & 0.11 & 10.1 & 0.23 \\
\hline & 100 & 1.1 & 0.11 & 8.6 & 0.23 \\
\hline \multirow[t]{5}{*}{100} & 0 & 1.3 & 0.11 & 7.6 & 0.18 \\
\hline & 25 & 1.0 & 0.09 & 16.5 & 0.18 \\
\hline & 50 & 1.0 & 0.09 & 26.2 & 0.13 \\
\hline & 75 & 1.0 & 0.11 & 11.5 & 0.16 \\
\hline & 100 & 0.9 & 0.08 & 11.0 & 0.18 \\
\hline Mean & & 1.1 & 0.09 & 10.1 & 0.17 \\
\hline Fpr. (MF × Co) & & $<0.001$ & $<0.001$ & $<0.001$ & $<0.001$ \\
\hline LSD (0.05) & & 0.1 & 0.01 & 4.02 & 0.05 \\
\hline
\end{tabular}

Values are means of three replicates. \%RR MF, percentage recommended rate of mineral fertilizer; $\%_{R R}$ Co, percentage recommended rate of compost; LSD, least significant difference.

2016 , the highest grain yield of $5.12 \mathrm{Mg} \mathrm{ha}^{-1}$ was recorded under $100 \%_{\mathrm{RR}} \mathrm{MF}+100 \%_{\mathrm{RR}}$ Co.

The conjoint application of nutrients significantly $(p<0.001)$ influenced soil organic $\mathrm{C}$, total $\mathrm{N}$, available $\mathrm{P}$, and exchangeable $\mathrm{K}$ at the end of the field study (Table 3 ). The application of $100 \%{ }_{\mathrm{RR}} \mathrm{MF}+100 \%_{\mathrm{RR}}$ Co always resulted in a lower soil organic $\mathrm{C}$ which was $10 \%$ lower than the control $0 \%_{\mathrm{RR}} \mathrm{MF}+0 \%_{\mathrm{RR}} \mathrm{Co}$ at the end of the 3-year field experiment. For total N, 75\% $\%_{\mathrm{RR}} \mathrm{MF}+$ $75 \%_{\mathrm{RR}} \mathrm{Co}, 100 \%_{\mathrm{RR}} \mathrm{MF}+75 \%_{\mathrm{RR}} \mathrm{Co}$, and $75 \%_{\mathrm{RR}} \mathrm{MF}+100 \%_{\mathrm{RR}} \mathrm{Co}$ recorded increased total $\mathrm{N}$ which was $38 \%$ relatively greater than the control at the end of the field study. After 2 years of amendment application, the soil exchangeable $\mathrm{K}$ of the different treatments generally increased with values ranging from 0.10 to $0.32 \mathrm{cmol}_{(+)} \mathrm{kg}^{-1}$ soil.

The highest added benefits in grain yield during the 2015, 2016, and 2017 major cropping seasons were $906.00 \mathrm{~kg}$ $\mathrm{ha}^{-1}\left(100 \%_{\mathrm{RR}} \mathrm{MF}+100 \%_{\mathrm{RR}} \mathrm{Co}\right), 2,327.80 \mathrm{~kg} \mathrm{ha}^{-1}\left(100 \%_{\mathrm{RR}} \mathrm{MF}\right.$ $\left.+25 \%_{\mathrm{RR}} \mathrm{Co}\right)$, and $903.20 \mathrm{~kg} \mathrm{ha}^{-1}\left(75 \%_{\mathrm{RR}} \mathrm{MF}+25 \%_{\mathrm{RR}} \mathrm{Co}\right)$, respectively (Figure 1). Antagonistic interactions were also recorded during the 2015 ( -26.80 to $-1,479.90 \mathrm{~kg} \mathrm{ha}^{-1}$ ), 2016 $\left(-34.40\right.$ to $\left.-2,028.90 \mathrm{~kg} \mathrm{ha}^{-1}\right)$, and 2017 major cropping seasons $\left(-195.40\right.$ to $\left.-2,340.80 \mathrm{~kg} \mathrm{ha}^{-1}\right)$ (Figure 1). The highest added benefit observed from the conjoint application of $100 \%{ }_{\mathrm{RR}} \mathrm{MF}$ $+25 \%_{\mathrm{RR}} \mathrm{Co}\left(2,327.80 \mathrm{~kg} \mathrm{ha}{ }^{-1}\right)$ was not significantly $(p>$ $0.05)$ different from the application of $50 \%_{\mathrm{RR}} \mathrm{MF}+25 \%_{\mathrm{RR}} \mathrm{Co}$ $\left(2,201.20 \mathrm{~kg} \mathrm{ha}^{-1}\right)$. Generally, more positive added effects were observed among the treatments in 2015 (36\%) and 2016 (24\%) compared to 2017 (4\%).

\section{Evaluation of Mechanisms Influencing Added Benefits}

The results showed a significant $(p \leq 0.05) \mathrm{N}$ availability from days 14 to 84 among the treatments (Table 4). In general, there were fluctuations in mineral $\mathrm{N}$ availability over the incubation period. However, on average, mineral $\mathrm{N}$ availability were 112.3, 102.5 , and $88.1 \mathrm{~kg} \mathrm{ha}^{-1}$ at 14,42 , and $84 \mathrm{DAI}$, respectively. It was also observed that the application of $100 \%_{\mathrm{RR}} \mathrm{MF}+50 \%_{\mathrm{RR}} \mathrm{Co}$ and $100 \%_{\mathrm{RR}} \mathrm{MF}+100 \%_{\mathrm{RR}}$ Co resulted in higher $\mathrm{N}$ availability than the initial soil mineral $\mathrm{N}$ content from 14 to 84 DAI (Table 4). Conjoint application of compost and mineral fertilizer also had a significant $(p \leq 0.05)$ influence on available $\mathrm{P}$ content among all the treatments throughout the incubation period (Table 4). Phosphorus content increased with values ranging from 9.16 to $17.79 \mathrm{~kg} \mathrm{ha}^{-1}$ relative to the initial $\mathrm{P}$ content of the soil prior to incubation $\left(8.04 \mathrm{~kg} \mathrm{ha}^{-1}\right)$. In general, the $\mathrm{P}$ content increased by $62 \%$ after 14 DAI.

The results showed that the treatments recorded highest NSI of 10 at the start of incubation (Table 5). The nutrient inputs did not have a significant $(p>0.05)$ effect on NSI. However, it was observed that, $\mathrm{N}$ synchrony scores generally reduced at the start of incubation to 84 DAI. Cumulatively, the highest NSI of 7.2 was recorded under $25 \%_{\mathrm{RR}} \mathrm{MF}+50 \%_{\mathrm{RR}}$ Co followed by $75 \%_{\mathrm{RR}} \mathrm{MF}+100 \%_{\mathrm{RR}} \mathrm{Co}(7.1)$. The least cumulative NSI was recorded under $0 \%_{\mathrm{RR}} \mathrm{MF}+75 \%_{\mathrm{RR}} \mathrm{Co}(4.2)$. The phosphorus synchrony scores and index were not significantly $(p>0.05)$ influenced by the conjoint application of compost and mineral fertilizer throughout the incubation period (Table 5). The highest PSI of 10 was recorded at the start of incubation. The highest PSI of 10 was recorded under the application of $100 \%_{R R} M F$ $+50 \%{ }_{\mathrm{RR}} \mathrm{Co}$ and $100 \%_{\mathrm{RR}} \mathrm{MF}+100 \%_{\mathrm{RR}}$ Co. Mean P synchrony scores recorded were 9.8, 6.5, and 8.9 at 14,42 , and 84 DAI, respectively.

The results showed that, nitrogen priming was significantly ( $p$ $\leq 0.05$ ) influenced by the treatments at 84 DAI (Table 6). At 14 DAI, almost all the treatment combinations recorded a negative $\mathrm{N}$ priming effect, with values ranging from -52.5 to $-3.2 \mathrm{mg}$ $\mathrm{kg}^{-1}$. The only treatment with a positive $\mathrm{N}$ priming effect at 14 DAI was $50 \%_{\mathrm{RR}} \mathrm{MF}+100 \%_{\mathrm{RR}}$ Co with $\mathrm{N}$ priming effect of $6.0 \mathrm{mg} \mathrm{kg}{ }^{-1}$. Alternating positive and negative priming effects was observed throughout the incubation period except $25 \%_{\mathrm{RR}} \mathrm{MF}$ $+50 \%_{\mathrm{RR}} \mathrm{Co}$ and $75 \%_{\mathrm{RR}} \mathrm{MF}+100 \%_{\mathrm{RR}}$ Co which gave a negative $\mathrm{N}$ priming effect from 14 to 84 DAI. Generally, the conjoint application of $75 \%_{\mathrm{RR}}$ Co with different $\%_{\mathrm{RR}}$ of mineral fertilizer 


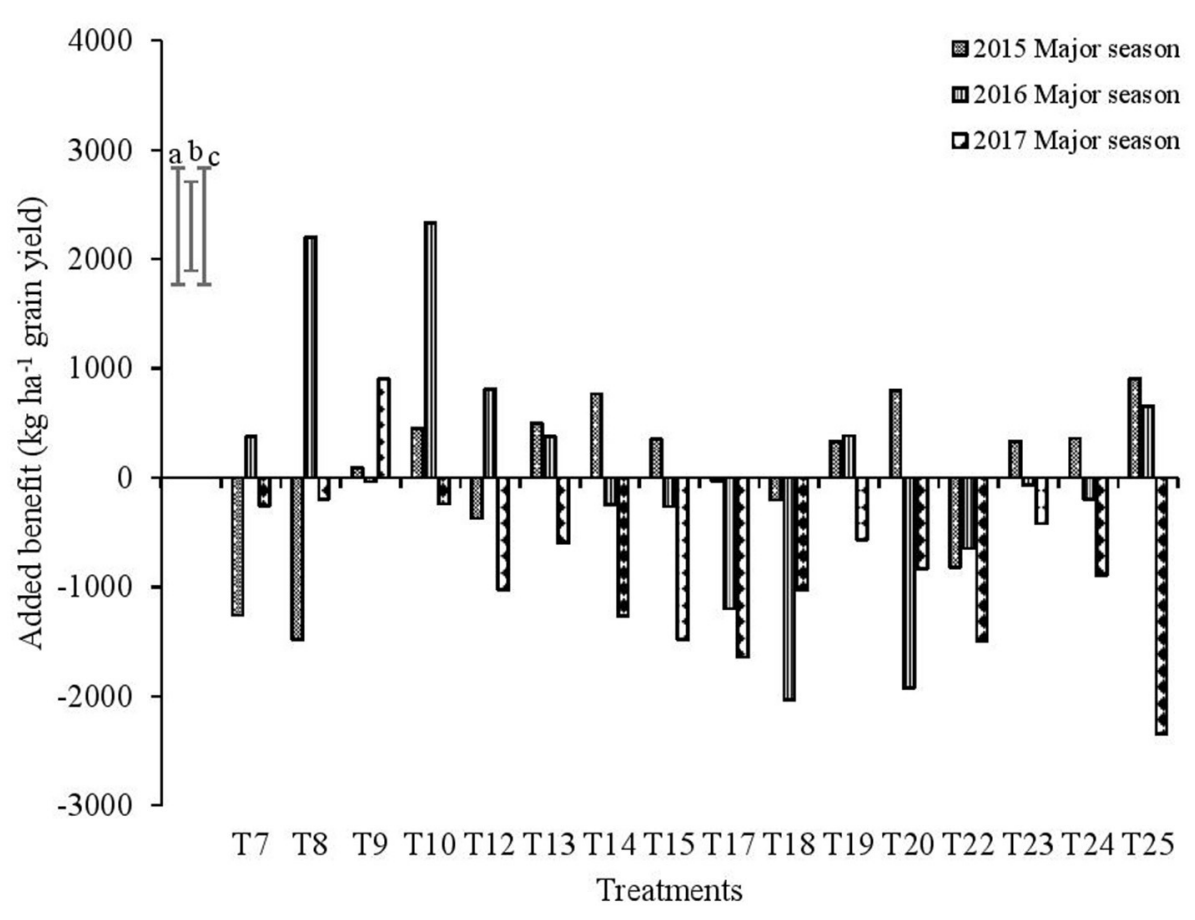

FIGURE 1 | Added benefit in maize grain yield from the combined application of mineral fertilizer and enriched compost.

resulted in positive $\mathrm{P}$ priming effect; $25 \%_{\mathrm{RR}} \mathrm{MF}+75 \%_{\mathrm{RR}} \mathrm{Co}$ recording the second highest $\mathrm{P}$ priming effect at $14 \mathrm{DAI}(1.92 \mathrm{mg}$ $\mathrm{kg}^{-1}$ ) which was statistically similar to $25 \%_{\mathrm{RR}} \mathrm{MF}+75 \%_{\mathrm{RR}} \mathrm{Co}$ $\left(1.92 \mathrm{mg} \mathrm{kg}^{-1}\right)$ at 14 DAI. It was observed that, approximately $38 \%$ of the treatment interactions recorded positive P priming effects at 14 DAI. Unlike the other treatments which had positive and negative fluctuations in the $\mathrm{P}$ priming effects, $50 \%_{\mathrm{RR}} \mathrm{MF}+$ $25 \%_{\mathrm{RR}} \mathrm{Co}, 50 \%_{\mathrm{RR}} \mathrm{MF}+50 \%_{\mathrm{RR}} \mathrm{Co}, 75 \%_{\mathrm{RR}} \mathrm{MF}+50 \%_{\mathrm{RR}} \mathrm{Co}$ and $100 \%_{\mathrm{RR}} \mathrm{MF}+100 \%_{\mathrm{RR}}$ Co recorded a negative P priming effect throughout the incubation period.

With the exception of organic carbon and exchangeable $\mathrm{K}$ contents which were not significantly $(p>0.05)$ influenced by the treatments at the end of $84 \mathrm{DAI}$, total $\mathrm{N}$ and available $\mathrm{P}$ were significantly $(p \leq 0.05)$ influenced by the application of compost and mineral fertilizer under the different treatments (Table 7). There was a general reduction of $48 \%$ in soil organic carbon content at $84 \mathrm{DAI}$ relative to the soil organic carbon content before incubation (1.24\%). At the end of the 84 days incubation period, it was observed that the conjoint application of compost and mineral fertilizer significantly $(p \leq 0.05)$ increased total $\mathrm{N}$ contents of the treatments from 0.08 to $0.11 \%$. The highest nitrogen content of $0.11 \%$ was recorded in $100 \%_{\mathrm{RR}} \mathrm{MF}+$ $25 \%_{\mathrm{RR}} \mathrm{Co}, 75 \%_{\mathrm{RR}} \mathrm{MF}+50 \%_{\mathrm{RR}} \mathrm{Co}$, and $75 \%_{\mathrm{RR}} \mathrm{MF}+75 \%_{\mathrm{RR}} \mathrm{Co}$. Available P contents of the treatments were also significantly $(p \leq$ 0.05 ) increased by $21 \%$ following the application of compost and mineral fertilizer at the end of the incubation period (Table 7). The available $\mathrm{P}$ content of the different treatments ranged from 3.69 to $12.78 \mathrm{mg} \mathrm{kg}^{-1}$ with $50 \%_{\mathrm{RR}} \mathrm{MF}+100 \%_{\mathrm{RR}}$ Co recording the highest available $\mathrm{P}$ content $\left(12.78 \mathrm{mg} \mathrm{kg}^{-1}\right)$ while there was a decrease in exchangeable $\mathrm{K}$ content at 84 DAI. The exchangeable
$\mathrm{K}$ content of the treatments ranged from 0.16 to $0.59 \mathrm{cmol}_{(+)}$ $\mathrm{kg}^{-1}$ compared to the initial soil exchangeable $\mathrm{K}$ content of $0.76 \mathrm{cmol}_{(+)} \mathrm{kg}^{-1}$.

The results showed that all the nutrient ratios were not significantly $(p>0.05)$ increased by the conjoint application of compost and mineral fertilizer (Table 8). Generally, Ca:Mg ratio and $\mathrm{P}: \mathrm{Zn}$ increased at $84 \mathrm{DAI}$. The highest balanced Ca:Mg ratio of 7:1 was recorded for the $50 \%_{\mathrm{RR}} \mathrm{MF}+50 \%_{\mathrm{RR}}$ Co treatment while treatment $75 \%_{\mathrm{RR}} \mathrm{MF}+0 \%_{\mathrm{RR}} \mathrm{Co}$ recorded the highest balanced P:Zn ratio of 31:1.

Three principal components were found to cumulatively explain approximately $86 \%$ of the variation among nutrient synchrony, priming, GFI, and balanced ratios of nutrients (Table 9). The first two principal components explained approximately $66 \%$ of the variation resulting from the interaction among the different mechanisms (Table 9). Principal component 1 (PC 1) explained $39 \%$ of the variation, which was highly contributed by priming effect (PE) and balanced nutrient ratios (BR) with Eigen vector scores of 0.64 and 0.51 , respectively (Table 9). Principal component 2 (PC 2) explained 27\% of the variation, which was highly contributed by nutrient synchrony (NS). Principal component 3 (PC 3) explained approximately $20 \%$ of the variation which was highly contributed by balanced nutrient ratios and GFI (Table 9). The equations derived from the principal components in relation to the mechanisms influencing the interactive effect in maize grain yield is as follows:

Added benefit $=0.64 \mathrm{PE}+0.82 \mathrm{NS}+0.71 \mathrm{BR}+0.70 \mathrm{GFI}$ 
TABLE 4 | Effect of compost and mineral fertilizer application on nutrient availability.

\begin{tabular}{|c|c|c|c|c|c|c|c|}
\hline \multirow{2}{*}{$\begin{array}{l}\text { Nutrient input } \\
\text { Mineral fertilizer (\%RR) }\end{array}$} & \multirow[b]{2}{*}{ Compost (\%RR) } & \multicolumn{3}{|c|}{$\begin{array}{l}\text { Mineral } \mathrm{N} \text { availability } \\
\qquad\left(\mathrm{kg} \mathrm{ha}^{-1}\right)\end{array}$} & \multicolumn{3}{|c|}{$\begin{array}{l}\text { Phosphorus availability } \\
\qquad\left(\mathrm{kg} \mathrm{ha}^{-1}\right)\end{array}$} \\
\hline & & 14 DAl & 42 DAI & 84 DAl & 14 DAl & 42 DAl & 84 DAl \\
\hline \multirow[t]{5}{*}{0} & 0 & 75.50 & 57.30 & 96.80 & 9.88 & 10.31 & 9.99 \\
\hline & 25 & 117.00 & 82.30 & 65.30 & 11.97 & 9.91 & 11.00 \\
\hline & 50 & 78.60 & 87.50 & 70.30 & 12.01 & 11.90 & 16.65 \\
\hline & 75 & 76.40 & 89.50 & 67.70 & 12.87 & 11.15 & 7.38 \\
\hline & 100 & 83.80 & 60.60 & 70.10 & 16.49 & 13.26 & 12.18 \\
\hline \multirow[t]{5}{*}{25} & 0 & 99.10 & 119.20 & 70.40 & 9.16 & 9.26 & 11.47 \\
\hline & 25 & 94.40 & 106.30 & 70.50 & 10.68 & 11.21 & 7.27 \\
\hline & 50 & 80.80 & 100.90 & 36.20 & 11.83 & 11.20 & 10.13 \\
\hline & 75 & 81.80 & 92.60 & 77.90 & 16.00 & 11.78 & 9.31 \\
\hline & 100 & 77.60 & 63.10 & 74.70 & 12.32 & 16.05 & 9.14 \\
\hline \multirow[t]{5}{*}{50} & 0 & 89.50 & 80.00 & 94.90 & 9.39 & 17.91 & 13.84 \\
\hline & 25 & 111.60 & 85.70 & 82.40 & 11.01 & 13.09 & 11.28 \\
\hline & 50 & 89.30 & 149.90 & 118.10 & 11.19 & 12.49 & 9.53 \\
\hline & 75 & 84.90 & 101.00 & 101.50 & 15.19 & 14.33 & 9.40 \\
\hline & 100 & 112.80 & 82.20 & 99.20 & 11.31 & 15.43 & 25.55 \\
\hline \multirow[t]{5}{*}{75} & 0 & 157.30 & 76.00 & 118.90 & 11.85 & 14.77 & 10.62 \\
\hline & 25 & 168.80 & 140.40 & 95.70 & 11.86 & 19.93 & 9.26 \\
\hline & 50 & 115.50 & 147.60 & 105.80 & 13.63 & 12.58 & 10.98 \\
\hline & 75 & 116.20 & 110.40 & 82.70 & 15.34 & 15.23 & 11.59 \\
\hline & 100 & 138.10 & 52.20 & 66.70 & 17.79 & 21.44 & 11.90 \\
\hline \multirow[t]{5}{*}{100} & 0 & 203.70 & 150.60 & 105.20 & 10.85 & 14.52 & 13.13 \\
\hline & 25 & 161.10 & 99.70 & 95.20 & 16.81 & 16.14 & 13.99 \\
\hline & 50 & 170.40 & 137.50 & 134.90 & 15.79 & 16.63 & 13.84 \\
\hline & 75 & 102.60 & 152.00 & 95.20 & 12.92 & 15.44 & 10.60 \\
\hline & 100 & 124.80 & 137.50 & 107.00 & 17.37 & 16.65 & 14.71 \\
\hline Mean & & 112.30 & 102.50 & 88.10 & 13.02 & 14.10 & 11.79 \\
\hline Fpr. (MF × Co) & & 0.012 & 0.003 & $<0.001$ & $<0.001$ & 0.029 & 0.015 \\
\hline LSD (0.05) & & 36.99 & 40.23 & 22.58 & 2.73 & 4.14 & 6.31 \\
\hline CV (\%) & & 20.10 & 23.90 & 15.60 & 12.80 & 17.90 & 32.70 \\
\hline
\end{tabular}

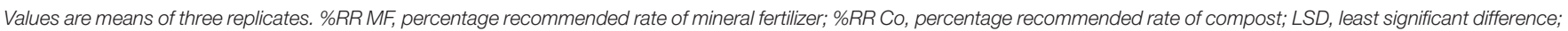
$D A l$, days after incubation. The initial mineral $\mathrm{N}$ release is $106.84 \mathrm{~kg} \mathrm{ha}^{-1}$. The initial $P$ release is $8.04 \mathrm{~kg} \mathrm{ha}^{-1}$.

The treatments were grouped into three major clusters with treatments 4,21 , and 23 being highly influenced by balanced nutrient ratios (Figure 2). The second cluster of treatments were treatments $7,2,13,16$, and 17 . The interactive effect resulting from these treatments were influenced by priming mechanism. The last cluster was made up of the remaining 17 treatments, which was distributed among the four mechanisms.

\section{DISCUSSION}

It is widely reported that, crop growth and yield are a function of the product of the crop's genetic make-up and the prevailing environmental conditions. Thus, low soil nutrients will limit crop growth and yield (4). Due to the generally low fertility status of the soil at the study area, it was expected that, the application of mineral fertilizer and compost to the maize crop would increase grain yield. On the other hand, Golabi et al. (36) and Fening et al. (37) suggested that, cattle manure compost could be a good substitute for NPK in maize production as they observed no significant difference in maize grain yields. Throughout the three cropping seasons, the grain yield of maize obtained from sole mineral fertilizer $\left(100 \%_{\mathrm{RR}} \mathrm{MF}+0 \%_{\mathrm{RR}} \mathrm{Co}\right)$ was significantly different $(p \leq 0.05)$ from the sole compost $\left(0 \%_{\mathrm{RR}} \mathrm{MF}+\right.$ $\left.100 \%{ }_{\mathrm{RR}} \mathrm{Co}\right)$. The general increase in average grain yield across the cropping years can be attributed to the cumulative effect as well as the residual impact of nutrients left in the soil after harvest over the successive years (38). The general increase in grain yield after the 2015 cropping season corroborates the findings by Kombiok et al. (38) who observed general increases in grain yield and yield components of maize after the first year of cropping with percentage grain yield increase of $57 \%$ under plots organically amended in 2009 relative to 2008, indicating the positive benefits of the residual effects of the treatments applied. 
TABLE 5 | Nutrient synchrony index as influenced by compost and mineral fertilizer application.

\begin{tabular}{|c|c|c|c|c|c|c|c|c|c|}
\hline \multirow{2}{*}{$\frac{\text { Nutrient input }}{\text { Mineral fertilizer (\%RR) }}$} & \multirow[b]{2}{*}{ Compost (\%RR) } & \multicolumn{3}{|c|}{ Nitrogen synchrony scores } & \multirow[t]{2}{*}{ NSI } & \multicolumn{3}{|c|}{ Phosphorus synchrony scores } & \multirow[t]{2}{*}{ PSI } \\
\hline & & 14DAl & 42DAl & 84DAl & & 14DAl & 42DAl & 84DAl & \\
\hline \multirow[t]{5}{*}{0} & 0 & 7.5 & 10.0 & 2.0 & 6.5 & 8.9 & 7.0 & 9.2 & 8.4 \\
\hline & 25 & 9.9 & 6.2 & 1.2 & 5.8 & 10.0 & 1.2 & 10.0 & 7.1 \\
\hline & 50 & 6.3 & 7.0 & 2.6 & 5.3 & 10.0 & 4.3 & 10.0 & 8.1 \\
\hline & 75 & 7.5 & 4.0 & 1.0 & 4.2 & 10.0 & 2.1 & 6.8 & 6.3 \\
\hline & 100 & 7.2 & 7.1 & 3.3 & 5.9 & 10.0 & 8.2 & 8.6 & 8.9 \\
\hline \multirow[t]{5}{*}{25} & 0 & 9.1 & 4.0 & 1.0 & 4.7 & 8.5 & 4.0 & 8.1 & 6.8 \\
\hline & 25 & 8.9 & 4.0 & 1.6 & 4.8 & 9.8 & 2.8 & 6.8 & 6.4 \\
\hline & 50 & 8.2 & 7.0 & 6.3 & 7.2 & 10.0 & 5.0 & 8.6 & 7.9 \\
\hline & 75 & 10.0 & 4.0 & 1.0 & 5.0 & 10.0 & 2.8 & 8.5 & 7.1 \\
\hline & 100 & 7.3 & 7.0 & 3.3 & 5.9 & 10.0 & 7.0 & 8.8 & 8.6 \\
\hline \multirow[t]{5}{*}{50} & 0 & 8.4 & 4.4 & 1.0 & 4.6 & 8.7 & 10.0 & 8.8 & 9.2 \\
\hline & 25 & 10.0 & 7.0 & 1.0 & 6.0 & 9.8 & 5.7 & 8.4 & 8.0 \\
\hline & 50 & 8.6 & 4.0 & 1.0 & 4.5 & 9.9 & 5.3 & 8.1 & 7.8 \\
\hline & 75 & 9.2 & 4.0 & 1.0 & 4.7 & 10.0 & 6.1 & 9.0 & 8.4 \\
\hline & 100 & 9.7 & 6.4 & 1.1 & 5.7 & 10.0 & 7.5 & 10.0 & 9.1 \\
\hline \multirow[t]{5}{*}{75} & 0 & 8.9 & 4.0 & 1.0 & 4.6 & 9.3 & 7.7 & 8.1 & 8.4 \\
\hline & 25 & 10.0 & 4.0 & 1.0 & 5.0 & 10.0 & 7.0 & 8.7 & 8.6 \\
\hline & 50 & 9.6 & 4.0 & 1.0 & 4.9 & 10.0 & 5.7 & 8.6 & 8.1 \\
\hline & 75 & 9.4 & 4.0 & 1.4 & 4.9 & 10.0 & 6.4 & 8.5 & 8.3 \\
\hline & 100 & 9.8 & 7.0 & 4.6 & 7.1 & 10.0 & 10.0 & 9.8 & 9.9 \\
\hline \multirow[t]{5}{*}{100} & 0 & 10.0 & 4.0 & 1.0 & 5.0 & 9.5 & 8.7 & 10.0 & 9.4 \\
\hline & 25 & 10.0 & 2.9 & 1.0 & 4.6 & 10.0 & 8.6 & 10.0 & 9.5 \\
\hline & 50 & 10.0 & 1.0 & 4.0 & 5.0 & 10.0 & 10.0 & 10.0 & 10.0 \\
\hline & 75 & 9.6 & 4.0 & 1.9 & 5.1 & 9.8 & 8.0 & 7.9 & 8.6 \\
\hline & 100 & 10.0 & 2.3 & 1.0 & 4.4 & 10.0 & 10.0 & 10.0 & 10.0 \\
\hline Mean & & 9.0 & 4.9 & 1.9 & 5.3 & 9.8 & 6.5 & 8.9 & 8.4 \\
\hline Fpr(MF × Co) & & 0.534 & 0.990 & 0.398 & 0.927 & 0.927 & 0.943 & 0.838 & 0.853 \\
\hline
\end{tabular}

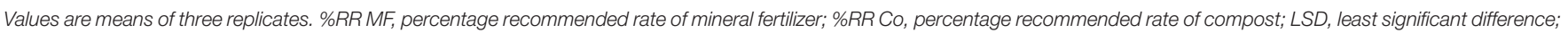
NS, not significant; DAl, days after incubation; NSI, nitrogen synchrony index; PSI, phosphorus synchrony index. The initial N and P synchrony score is 10.

Nutrient interaction in crop plants is a major factor known to influence the yield of annual crops since the supply of one nutrient can influence the absorption and utilization of other nutrients $(6,7)$. From this study, significant $(p=0.001, p \leq 0.001$, $p \leq 0.001)$ nutrient interaction effects were recorded with respect to grain yields of maize in 2015, 2016, and 2017, respectively (Figure 1). The added disadvantages (antagonistic interactions) which occurred in most of the treatments, especially in 2017 could be due to the relatively low yield produced by the conjoint application of mineral fertilizer and compost at harvest relative to grain yield from either sole compost or mineral fertilizer (Table 2). Similarly, Gentile et al. (39) observed antagonistic interactions from the conjoint application of mineral fertilizer and organic inputs. Roy et al. (5) and Bindraban et al. (40) reported that, antagonistic interactions resulted mainly from imbalanced nutrient supply and suboptimal nutrient ratios required for the proper growth and development of crops. The nutrient ratios determined in this study were lower than the standard balanced ratios as recommended by Sait $(25,26)$. This could have contributed to the negative added benefits in grain yield of maize observed in this study. The positive added benefits observed in this study was greater than those reported by Nhamo (9), following the application of various combinations of cattle manure and mineral fertilizer. Generally, the results obtained from the added benefits in grain yield are similar to the findings of Iqbal et al. (11) who emphasized that, higher grain yield of maize was due to the beneficial effects of compost in supplying nutrients other than $\mathrm{N}$ and $\mathrm{P}$. The compost used in this study had $\mathrm{Ca}(2.2 \%), \mathrm{Mg}(2.9 \%), \mathrm{Mn}\left(50 \mathrm{mg} \mathrm{kg}^{-1}\right), \mathrm{Zn}\left(110.9 \mathrm{mg} \mathrm{kg}^{-1}\right)$, and Fe $\left(445.2 \mathrm{mg} \mathrm{kg}^{-1}\right)$, which could have played a complementary role in increasing grain yield of maize and consequently added benefits. This attests to earlier reports by Negassa et al. (41) and Wang et al. (42).

Organic amendments contain nutrients that are released at a rate determined by their resource quality or biochemical characteristics. Hadas and Portnoy (43) emphasized that, there is a balance between the amount of available $\mathrm{N}$ through microbial decomposition of compost and the amount of $\mathrm{N}$ assimilated by the microbes that feed on the compost. Carbon content and C:N ratio of organic amendments are important indices for assessing 
TABLE 6 | Nutrient priming effect as influenced by combined application of compost and mineral fertilizer.

\begin{tabular}{|c|c|c|c|c|c|c|}
\hline \multirow[b]{2}{*}{ Nutrient input } & \multicolumn{3}{|c|}{$\begin{array}{l}\text { Nitrogen priming effect } \\
\qquad\left(\mathrm{mg} \mathrm{kg}^{-1}\right)\end{array}$} & \multicolumn{3}{|c|}{$\begin{array}{l}\text { Phosphorus priming effect } \\
\qquad\left(\mathrm{mg} \mathrm{kg}^{-1}\right)\end{array}$} \\
\hline & 14 DAl & 42 DAl & 84 DAl & 14 DAl & 42 DAl & 84 DAl \\
\hline $25 \%_{\mathrm{RR}} \mathrm{MF}+25 \%{ }_{\mathrm{RR}} \mathrm{Co}$ & -24.60 & -19.00 & 15.80 & -0.29 & 1.18 & -2.60 \\
\hline $50 \%_{\mathrm{RR}} \mathrm{MF}+25 \%_{\mathrm{RR}} \mathrm{Co}$ & -11.30 & -9.70 & 9.50 & -0.24 & -2.21 & -1.78 \\
\hline $75 \%_{R R} M F+25 \%_{R R}$ Co & -16.50 & 19.70 & 4.10 & -1.04 & 2.79 & -1.18 \\
\hline $100 \%_{R R} M F+25 \%_{R R}$ Co & -43.60 & -37.90 & 10.80 & 1.93 & 1.02 & -0.07 \\
\hline $25 \%_{\mathrm{RR}} \mathrm{MF}+50 \%{ }_{\mathrm{RR}} \mathrm{Co}$ & -12.20 & -24.30 & -3.80 & 0.27 & 0.18 & -4.00 \\
\hline $50 \%_{R R} M F+50 \%_{R R}$ Co & -3.20 & 19.90 & 24.80 & -0.17 & -3.50 & -5.48 \\
\hline $75 \%_{\mathrm{RR}} \mathrm{MF}+50 \%_{\mathrm{RR}} \mathrm{Co}$ & -24.00 & 20.70 & 6.70 & -0.17 & -1.89 & -3.15 \\
\hline $100 \%{ }_{R R} M F+50 \%$ RR Co & -19.80 & -21.70 & 28.10 & 1.41 & 0.26 & -2.97 \\
\hline $25 \%$ RRMF $+75 \%$ RRCo & -10.60 & -29.40 & 18.30 & 1.92 & 0.84 & 0.23 \\
\hline $50 \%_{\mathrm{RR}} \mathrm{MF}+75 \%_{\mathrm{RR}} \mathrm{Co}$ & -4.20 & -5.60 & 17.90 & 1.40 & -2.21 & -0.91 \\
\hline $75 \%_{\mathrm{RR}} \mathrm{MF}+75 \%_{\mathrm{RR}} \mathrm{Co}$ & -22.50 & 1.10 & -3.60 & 0.25 & -0.19 & 1.79 \\
\hline $100 \%$ RRMF + 75\%RR Co & -52.50 & -15.40 & 9.60 & -0.46 & 0.04 & 0.04 \\
\hline $25 \%{ }_{R R} M F+100 \%{ }_{R R}$ Co & -16.40 & -29.70 & 15.60 & -1.73 & 1.92 & -2.26 \\
\hline $50 \%_{\mathrm{RR}} \mathrm{MF}+100 \%_{\mathrm{RR}} \mathrm{Co}$ & 6.00 & -0.60 & 15.50 & -2.34 & -2.71 & 4.76 \\
\hline $75 \%_{\mathrm{RR}} \mathrm{MF}+100 \%_{\mathrm{RR}} \mathrm{Co}$ & -15.30 & -13.60 & -12.70 & -0.33 & 1.86 & -0.46 \\
\hline $100 \%_{R R} M F+100 \%_{R R}$ Co & -45.10 & -8.20 & 14.30 & -0.04 & -0.4 & -0.30 \\
\hline Fpr. & 0.559 & 0.214 & 0.009 & 0.186 & 0.620 & 0.476 \\
\hline LSD (0.05) & NS & NS & 15.64 & NS & NS & NS \\
\hline
\end{tabular}

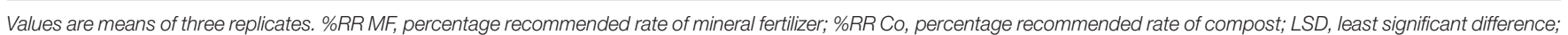
$D A l$, days after incubation.

their ability to decompose and release nutrients. However, most soil amendments rarely release adequate nutrients for optimum crop growth and yield (44). The results of this study are contrary to the general rule for nutrient release from organic inputs as proposed by Fairhurst (45) that organic inputs with an $\mathrm{N}$ content $<2.5 \%$ or $\mathrm{C}$ : $\mathrm{N}$ ratio $>16$ will cause immobilization of soil nutrients over a prolonged period. The highest nitrogen availability among the treatments was mostly recorded within 2 weeks of incorporation into the soil allowing a ready supply of nutrients to crops. The application of $75 \%_{\mathrm{RR}} \mathrm{MF}$ and $100 \%_{\mathrm{RR}} \mathrm{MF}$ generally resulted in a peak nitrogen availability at $14 \mathrm{DAI}$, whereas the application of $50 \%_{\mathrm{RR}} \mathrm{Co}$ and $75 \%_{\mathrm{RR}} \mathrm{Co}$ staggered nitrogen availability till peaking at 42 DAI. Phosphorus availability on the other hand, peaked at $42 \mathrm{DAI}$, corresponding to $50 \%$ flowering during the maize crop in the field.

Maize crops have specific nutrient requirements at the different phenological stages of crop growth (20). Hence, synchronizing nutrient supply to crop demand will cause reduction in nutrient losses and provide optimal nutrition for the growth of crops (46). In this current study, the highest $\mathrm{N}$ and $\mathrm{P}$ synchrony scores of 10 were recorded at the beginning of incubation, after which the nutrient synchrony scores began to reduce. In a related study, similar observations were made by Badu (27) who reported the highest NSI and PSI of 10 at 7 DAI for all the nutrient inputs applied. However, unlike Badu (27) who reported very low NSI of 1 at 70 DAI, the average NSI recorded at the end of incubation (84 DAI) in this study was 5.3. The NSI presented in Table 5 suggests that on the average, 53\% (NSI =
5.3) of the nitrogen requirements of maize was supplied by the different treatments to synchronize with crop nitrogen demand. Among the treatments, $25 \%{ }_{\mathrm{RR}} \mathrm{MF}+50 \%{ }_{\mathrm{RR}}$ Co best synchronized the nitrogen demand of maize with $\mathrm{N}$ release by supplying $72 \%$ $(\mathrm{NSI}=7.2)$ of the nitrogen requirements of maize, cumulatively throughout the 84 days incubation period, followed by $71 \%$ $(\mathrm{NSI}=7.1)$ from $75 \%_{\mathrm{RR}} \mathrm{MF}+100 \%_{\mathrm{RR}} \mathrm{Co}$. Even though the application of $25 \%{ }_{\mathrm{RR}} \mathrm{MF}+50 \%_{\mathrm{RR}}$ Co did not produce the highest grain yield of maize, $25 \%_{\mathrm{RR}} \mathrm{MF}+50 \%_{\mathrm{RR}}$ Co produced grain yield which was $52 \%$ greater than the control during the 2017 cropping season (Table 2). Similarly, $75 \%_{\mathrm{RR}} \mathrm{MF}+100 \%_{\mathrm{R} R}$ Co produced grain yield which was also $83.25 \%$ greater than the control in 2017. However, this was not significantly different $(p>0.05)$ from $50 \%_{\mathrm{RR}} \mathrm{MF}+100 \%_{\mathrm{RR}}$ Co which produced grain yield which was $98 \%$ relatively superior to the control.

From Table 6, it can be observed that, nitrogen priming was not significantly $(p>0.05)$ influenced by amendment application during the incubation period. In a similar study by Badu (27), the application of $100 \%_{\mathrm{RR}} \mathrm{MF}+100 \%_{\mathrm{RR}} \mathrm{CM}$ resulted in the highest $\mathrm{N}$ availability with a consequent positive $\mathrm{N}$ priming effect of $93.72,46.13,58.69$, and $50.46 \mathrm{~kg} \mathrm{ha}^{-1}$ at $7,28,42$, and $56 \mathrm{DAI}$, respectively. On the contrary, the application of $50 \%{ }_{\mathrm{RR}} \mathrm{MF}+50 \%_{\mathrm{RR}} \mathrm{Co}$ resulted in the second-best total $\mathrm{N}$ priming effect of $12.4 \mathrm{~kg} \mathrm{ha}^{-1}$ at $42 \mathrm{DAI}$ and $33.0 \mathrm{~kg} \mathrm{ha}^{-1}$ at 84 DAI. The treatment with the best total $\mathrm{N}$ priming effect was $25 \%_{\mathrm{RR}} \mathrm{MF}+75 \%_{\mathrm{RR}}$ Co. From the results, the type of $\mathrm{N}$ priming observed in this study could be described as "real" priming effect. According to Kuzyakov (22), though nutrient 
TABLE 7 | Effect of compost and mineral fertilizer application on general soil fertility improvement at the end of incubation (84 DAl).

\begin{tabular}{|c|c|c|c|c|c|}
\hline \multicolumn{6}{|l|}{ Nutrient input } \\
\hline $\begin{array}{l}\text { Mineral } \\
\text { fertilizer (\%RR) }\end{array}$ & $\begin{array}{c}\text { Compost } \\
\text { (\%RR) }\end{array}$ & $\begin{array}{c}\text { Org. C } \\
\text { (\%) }\end{array}$ & $\begin{array}{c}\text { Total N } \\
\text { (\%) }\end{array}$ & $\begin{array}{c}\text { Av.P } \\
\left(\mathrm{mg} \mathrm{kg}^{-1}\right)\end{array}$ & $\begin{array}{c}\text { Exch. K } \\
{\left[\mathrm{cmol}_{(+)} \mathbf{k g}^{-1}\right]}\end{array}$ \\
\hline \multirow[t]{5}{*}{0} & 0 & 0.83 & 0.08 & 5.00 & 0.24 \\
\hline & 25 & 0.96 & 0.08 & 5.50 & 0.16 \\
\hline & 50 & 0.69 & 0.10 & 8.33 & 0.24 \\
\hline & 75 & 0.89 & 0.10 & 3.69 & 0.30 \\
\hline & 100 & 0.71 & 0.10 & 6.09 & 0.34 \\
\hline \multirow[t]{5}{*}{25} & 0 & 0.86 & 0.09 & 5.73 & 0.35 \\
\hline & 25 & 0.73 & 0.09 & 3.64 & 0.22 \\
\hline & 50 & 0.76 & 0.08 & 5.06 & 0.33 \\
\hline & 75 & 0.67 & 0.09 & 4.66 & 0.40 \\
\hline & 100 & 0.81 & 0.09 & 4.57 & 0.34 \\
\hline \multirow[t]{5}{*}{50} & 0 & 1.00 & 0.09 & 6.92 & 0.24 \\
\hline & 25 & 1.00 & 0.08 & 5.64 & 0.26 \\
\hline & 50 & 0.85 & 0.10 & 4.76 & 0.27 \\
\hline & 75 & 0.87 & 0.08 & 4.70 & 0.41 \\
\hline & 100 & 0.73 & 0.08 & 12.78 & 0.31 \\
\hline \multirow[t]{5}{*}{75} & 0 & 0.71 & 0.09 & 5.31 & 0.26 \\
\hline & 25 & 1.04 & 0.09 & 4.63 & 0.26 \\
\hline & 50 & 0.79 & 0.11 & 5.49 & 0.30 \\
\hline & 75 & 0.93 & 0.11 & 5.80 & 0.59 \\
\hline & 100 & 0.83 & 0.10 & 5.95 & 0.37 \\
\hline \multirow[t]{5}{*}{100} & 0 & 1.02 & 0.09 & 6.56 & 0.30 \\
\hline & 25 & 0.83 & 0.11 & 6.99 & 0.31 \\
\hline & 50 & 0.89 & 0.10 & 6.92 & 0.37 \\
\hline & 75 & 0.85 & 0.10 & 5.30 & 0.34 \\
\hline & 100 & 0.72 & 0.10 & 7.36 & 0.36 \\
\hline Mean & & 0.84 & 0.09 & 5.90 & 0.31 \\
\hline Fpr. (MF × Co) & & 0.993 & 0.028 & 0.015 & 0.079 \\
\hline LSD (0.05) & & 0.51 & 0.01 & 3.16 & 0.13 \\
\hline CV (\%) & & 37.40 & 9.70 & 32.70 & 24.70 \\
\hline
\end{tabular}

Values are means of three replicates. \%RR MF, percentage recommended rate of mineral fertilizer; \%RR Co, percentage recommended rate of compost; LSD, least significant difference; DAl, days after incubation.

priming occurs immediately after the addition of substrates, "real" priming may be staggered for several days or weeks after substrate addition as was also observed in this study. The negative "real" priming of $\mathrm{N}$ generally observed at the beginning of incubation could be due to the $\mathrm{C}: \mathrm{N}$ ratio of the compost used in addition to the mineral fertilizer $(\mathrm{C}: \mathrm{N}$ ratio $=17.76)$, which led to a microbial immobilization of Kuzyakov et al. (21) reported that, substrates with $\mathrm{C}: \mathrm{N}$ ratio $>10$ leads to negative priming effect, whereas those with $\mathrm{C}: \mathrm{N}$ ratio $<8$ results in positive priming effect. The negative priming effect observed in most of the treatments could have accounted for the added disadvantage in the grain yield of maize (Figure 1). With regards to $\mathrm{P}$ priming, alternating positive and negative $\mathrm{P}$ priming effects were observed throughout the incubation period (Table 6). The results obtained corroborate the findings of Chowdhury (47) who reported that,
TABLE 8 | Effect of compost and mineral fertilizer application on balanced ratios of nutrients at the end of incubation (84 DAl).

\begin{tabular}{|c|c|c|c|c|c|}
\hline \multirow{2}{*}{$\begin{array}{l}\text { Nutrient input } \\
\text { Mineral } \\
\text { fertilizer (\%RR) }\end{array}$} & \multirow[b]{2}{*}{$\begin{array}{l}\text { Compost } \\
\text { (\%RR) }\end{array}$} & \multicolumn{4}{|c|}{ Nutrient ratios } \\
\hline & & Ca:Mg & $\mathrm{K}: \mathrm{Mg}$ & $P: Z n$ & Fe:Mn \\
\hline \multirow[t]{5}{*}{0} & 0 & 1.6 & 0.1 & 10.7 & 0.6 \\
\hline & 25 & 3.4 & 0.2 & 10.8 & 0.4 \\
\hline & 50 & 3.3 & 0.3 & 9.8 & 0.5 \\
\hline & 75 & 5.4 & 0.4 & 6.3 & 0.5 \\
\hline & 100 & 3.0 & 0.3 & 19.2 & 0.4 \\
\hline \multirow[t]{5}{*}{25} & 0 & 2.7 & 0.3 & 16.5 & 0.5 \\
\hline & 25 & 3.1 & 0.2 & 9.6 & 0.4 \\
\hline & 50 & 3.0 & 0.4 & 5.6 & 0.4 \\
\hline & 75 & 4.3 & 0.6 & 8.6 & 0.4 \\
\hline & 100 & 2.5 & 0.3 & 13.0 & 0.3 \\
\hline \multirow[t]{5}{*}{50} & 0 & 4.2 & 0.4 & 8.9 & 0.5 \\
\hline & 25 & 2.4 & 0.2 & 11.6 & 0.4 \\
\hline & 50 & 7.0 & 0.4 & 8.7 & 0.5 \\
\hline & 75 & 2.7 & 0.3 & 10.1 & 0.5 \\
\hline & 100 & 2.8 & 0.3 & 23.7 & 0.5 \\
\hline \multirow[t]{5}{*}{75} & 0 & 5.6 & 0.5 & 31.0 & 0.4 \\
\hline & 25 & 2.7 & 0.2 & 8.4 & 0.3 \\
\hline & 50 & 1.7 & 0.2 & 9.9 & 0.5 \\
\hline & 75 & 3.5 & 0.6 & 7.1 & 0.3 \\
\hline & 100 & 2.7 & 0.3 & 7.8 & 0.4 \\
\hline \multirow[t]{5}{*}{100} & 0 & 3.4 & 0.3 & 21.5 & 0.3 \\
\hline & 25 & 3.8 & 0.3 & 10.3 & 0.4 \\
\hline & 50 & 1.8 & 0.2 & 10.1 & 0.3 \\
\hline & 75 & 2.3 & 0.3 & 20.2 & 0.4 \\
\hline & 100 & 3.4 & 0.3 & 10.3 & 0.3 \\
\hline Mean & & 3.3 & 0.3 & 12.4 & 0.4 \\
\hline Fpr. (MF × Co) & & 0.117 & 0.351 & 0.557 & 0.871 \\
\hline LSD (0.05) & & 3.28 & 0.27 & 18.05 & 0.26 \\
\hline $\begin{array}{l}\text { Standard } \\
\text { balanced ratios }\end{array}$ & & $3: 1$ & $1: 1$ & $10: 1$ & $2: 1$ \\
\hline
\end{tabular}

Values are means of three replicates. \%RR MF, percentage recommended rate of mineral fertilizer; \%RR Co, percentage recommended rate of compost; LSD, least significant difference; $D A I$, days after incubation.

the application of nutrient amendments to the soil does not only cause mineralization (positive priming effect), but also temporal immobilization (negative priming effect). The positive priming effect could therefore be attributed to the active degradation of soil organic matter by microorganisms present in soil (47).

General soil fertility improvement as a possible mechanism for synergistic interactions mostly occurs as a consequence of the supply of essential nutrient elements in adequate proportions to the soil (24). Apart from total soil $\mathrm{N}$ and available $\mathrm{P}$ which increased at the end of $84 \mathrm{DAI}$, organic carbon and exchangeable $\mathrm{K}$ decreased (Table 7 ). The relatively weak response of the nutrient inputs could be due to the shortterm duration of the incubation experiment. Liza et al. (48) reported that, the integrated application of organic and inorganic 
TABLE 9 | Eigen values, percentage variation, and Eigen vectors explaining variations among mechanisms.

\begin{tabular}{lrcrr}
\hline & \multicolumn{4}{c}{ Principal components } \\
\cline { 2 - 5 } & PC 1 & PC 2 & PC 3 & PC 4 \\
\hline Eigen values & 1.57 & 1.07 & 0.79 & 0.57 \\
Variance (\%) & $\mathbf{3 9 . 1 8}$ & $\mathbf{2 6 . 7 9}$ & $\mathbf{1 9 . 6 9}$ & 14.34 \\
Cumulative variance (\%) & 39.18 & 65.97 & $\mathbf{8 5 . 6 6}$ & 100.00 \\
Eigen vectors & & & & \\
Nutrient synchrony & -0.30 & $\mathbf{0 . 8 2}$ & 0.05 & 0.48 \\
Priming effect & $\mathbf{0 . 6 4}$ & -0.20 & -0.01 & $\mathbf{0 . 7 4}$ \\
Balanced ratios of nutrients & $\mathbf{0 . 5 1}$ & 0.34 & $\mathbf{0 . 7 1}$ & -0.34 \\
GFI & -0.49 & -0.41 & $\mathbf{0 . 7 0}$ & 0.32 \\
\hline
\end{tabular}

GFI, general fertility improvement, PC, principal component. The bold Eigen vectors denote the significant variables with absolute loadings $\leq 0.50$ contributing to each princicpal component.

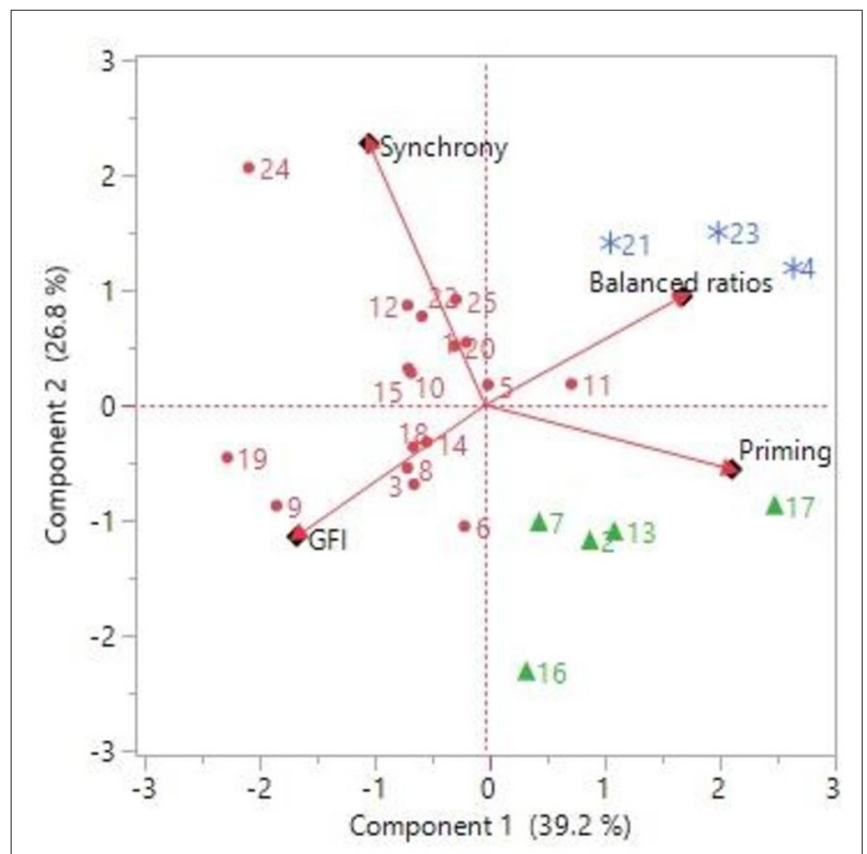

FIGURE 2 | A principal component bi-plot showing the relationship among the different mechanisms to added benefits.

fertilizers positively impacts the physical, chemical and biological properties of soil, especially in the long-term.

Comparing the initial organic carbon content to the final carbon content after incubation (1.24\%), the organic carbon was generally reduced from 1.24 to $0.84 \%$ at the end of the incubation period (Table 7). Organic inputs are known to be a major driving force of all soil microbial activities due to their high concentration of organic carbon (49). It was observed that, among the different soil parameters measured at the end of incubation, the conjoint application of compost and mineral fertilizer did not significantly $(p>0.05)$ influence total soil organic carbon. Similar findings were observed by Badu (27) who reported a lack of response of soil organic carbon to nutrient inputs.

Considering the initial low fertility status of the soil, it is likely that the conjoint application of compost and mineral fertilizer increased the total $\mathrm{N}$ and available $\mathrm{P}$ content of the soil, leading to improved soil fertility. Okalebo et al. (50) reported similar findings where the combined application of organic and inorganic nutrient sources resulted in general improvement in soil fertility. Though, the general increase in soil available P at the end of incubation is a desirable advantage in soil fertility improvement, it contradicts the findings by Sharpley (51) who observed a general decline in available soil $\mathrm{P}$ with time. Laboski and Lamb (52) and Spychaj-Fabisiak et al. (53), however, reported an increase in soil available $\mathrm{P}$ over time, during incubation. These authors opined that, the increase in soil available $\mathrm{P}$ over time was as a result of microbially mediated mineralization of soil organic $\mathrm{P}$, to form inorganic $\mathrm{P}$ at a faster rate. The increase in soil available $\mathrm{P}$ at $84 \mathrm{DAI}$ could also be due to the closed system used which might have reduced nutrient loss to the surrounding environment. The absence of plants in the incubated soil was also a contributing factor to increased $\mathrm{P}$ availability at the end of incubation, since the mineralized $\mathrm{P}$ was not taken up by plants as previously suggested by Opala et al. (54).

The study revealed that, nutrient ratios determined at the end of the incubation experiment were not significantly $(p>0.05)$ influenced by the conjoint application of compost and mineral fertilizer. According to Graeme Sait's Six secrets to Soil Test Success [Part 1, Part 2; $(25,26)$ ], balanced nutrient ratios of 3:1, 1:1, 10:1, and 2:1 for Ca:Mg, K:Mg, P:Zn, and Fe:Mn, respectively, are recommended for proper growth of crops. The K:Mg and Fe:Mn nutrient ratios recorded at the end of the incubation experiment were relatively lower than those recommended by Sait $(25,26)$. The high concentration of magnesium, phosphorus, and manganese in the soil reduced the uptake of potassium, zinc, and iron, respectively, and hence the low nutrient ratios. These imbalanced ratios of nutrients could have contributed to the antagonistic interactions in grain yield reported in Figure 1, confirming the assertion by Roy et al. (5) that, when nutrients required for proper growth and development of crops are supplied in an unbalanced proportion, antagonistic interactions will result. Furthermore, the imbalanced nutrient ratios could have been as a result of the soil $\mathrm{pH}$. Since most soil nutrients are available within the $\mathrm{pH}$ range of 6.0-7.5, the extremely acidic to slightly acidic pH (4.3-6.4) observed at the end of the incubation experiment could have resulted in the decline of nutrient availability leading to imbalanced nutrient ratios. These results are similar to those of Roem and Berendse (55) who further reported that, soil $\mathrm{pH}$ has a strong influence on nutrient ratios and that acidic $\mathrm{pH}$ of soil resulted in a decrease in the release of soil $\mathrm{P}$ and $\mathrm{K}$, thereby increasing $\mathrm{N}: \mathrm{P}$ and $\mathrm{N}: \mathrm{K}$ ratios. The balanced P:Zn ratios observed could be attributed to the rock-phosphate improved compost that was applied.

The positive effect of nutrient amendments on crop yields are attributed to different, but not mutually exclusive mechanisms (18). The PCA showed that, priming effect, balanced nutrient ratios, and nutrient synchrony were the most dominant mechanisms contributing most to the synergistic interactions 
resulting from the conjoint application of compost and mineral fertilizer application to the maize crops. These three mechanisms explained $66 \%$ of the variation in added benefits. The strong positive correlation between available soil P and PSI (0.51), and $\mathrm{K}: \mathrm{Mg}$ and Ca:Mg ratio (0.62) could have accounted for the synergistic interaction recorded in some of the treatments. The observations from this study are similar to that of Badu (27) who reported that NSI, PSI, and priming effect contributed $84 \%$ of the variation in added benefit resulting from the conjoint application of cattle manure and mineral fertilizer to maize.

\section{CONCLUSION}

This study has quantified added benefits/disadvantages resulting from the conjoint application of compost and mineral fertilizer to maize, and the underlying mechanisms resulting in added benefits in maize grain yield. Both synergistic and antagonistic interactions were observed among the treatments implying that, the conjoint application of compost and mineral fertilizer to crops may either be advantageous or disadvantageous. The dominant mechanisms contributing most to added benefits following the conjoint application of compost and mineral fertilizer application to maize crops were priming effect, nutrient ratio, and nutrient synchrony. This study has confirmed the null hypothesis of this research that, added benefits/disadvantages resulting from the conjoint application of compost and mineral fertilizer to maize is driven by underlying mechanisms such as

\section{REFERENCES}

1. Sanchez PA. Soil fertility and hunger in Africa. Science. (2002) 295:201920. doi: 10.1126/science.1065256

2. Henao J, Baanante C. Agricultural Production and Soil Nutrient Mining in Africa: Implications for Resource Conservation and Policy Development. Muscle Shoals, AL: International Center for Soil Fertility and Agricultural Development (2006). p. 13.

3. Wortmann CS, Sones K, eds. Fertilizer Use Optimization in Sub-Saharan Africa. Nairobi: CAB International (2017). p. 228.

4. Essel B, Abaidoo RC, Opoku A, Ewusi-Mensah N. Economically optimal rate for nutrient application to maize in the semi-deciduous forest zone of Ghana. J Soil Sci Plant Nutr. (2020) 10:1703-13. doi: 10.1007/s42729-020-00240-y

5. Roy RN, Finck A, Blair GJ, Tandon HLS. Plant Nutrition for Food Security. A Guide for Integrated Nutrient Management. Rome: Food and Agriculture Organization of the United Nations. FAO Fertilizer and Plant Nutrition Bulletin No. 16 (2006). p. 368.

6. Rietra RP, Heinen M, Dimkpa CO, Bindraban PS. Effects of nutrient antagonism and synergism on yield and fertilizer use efficiency. Commun Soil Sci Plant Anal. (2017). 48:1895-920. doi: 10.1080/00103624.2017.1407429

7. Fageria VD. Nutrient interactions in crop plants. J Plant Nutr. (2001). 24:1269-90. doi: 10.1081/PLN-100106981

8. Vanlauwe B, Palm C, Murwira H, Merckx R. Organic resource management in sub-Saharan Africa: validation of a residue quality-driven decision support system. Agronomie. (2002). 22:839-46. doi: 10.1051/agro:2002062

9. Nhamo N. An Evaluation of the Efficacy of Organic and Inorganic Fertilizer Combinations in Supplying Nitrogen to Crops (Master's thesis). University of Zimbabwe (2001).

10. Mucheru M, Mugendi D, Micheni A, Mugwe J, Kung'u J, Otor S, et al. Improved food production by use of soil fertility amendment strategies in the central highlands of Kenya. In: Bationo A, editor. Managing Nutrient Cycles improved nutrient synchrony, priming effect, GFI, and balanced ratios of nutrients. Thus, for further increases in grain yields and food security, interventions that aim at improving these mechanisms must be implemented.

\section{DATA AVAILABILITY STATEMENT}

The raw data supporting the conclusions of this article will be made available by the authors, without undue reservation.

\section{AUTHOR CONTRIBUTIONS}

$\mathrm{BE}, \mathrm{RA}$, and $\mathrm{AO}$ conceived the research and set up the experiment. $\mathrm{BE}, \mathrm{RA}, \mathrm{AO}$, and $\mathrm{NE}-\mathrm{M}$ planned the work, edited, revised, and made significant contributions. BE collected and analyzed the data and drafted the manuscript. All authors contributed to the article and approved the submitted version.

\section{FUNDING}

Kwame Nkrumah University of Science and Technology (KNUST) funded the research activities through a sub-agreement with the Alliance for Green Revolution in Africa (AGRA) under the AGRA Ph.D. Training in Soil Science in West Africa (2009 SHP 028) funded by Bill and Melinda Gates Foundation, Seattle, WA (Grant ID: OPP48790). to Sustain Soil Fertility in Sub-Saharan Africa. Nairobi: Academy Science Publishers (2004), p. 583-92.

11. Iqbal S, Thierfelder C, Khan HZ, Javeed HMR, Arif M, Shehzad M. Maximizing maize quality, productivity and profitability through a combined use of compost and nitrogen fertilizer in a semi-arid environment in Pakistan. Nutri Cycl Agroecosyst. (2017) 107:197-213. doi: 10.1007/s10705-017-9829-y

12. Togun AO, Akanbi WB. Comparative effectiveness of organic-based fertilizer to mineral fertilizer on tomato growth and fruit yield. Compost Sci Utiliz. (2003) 11:337-42. doi: 10.1080/1065657X.2003.10702143

13. Chivenge P, Vanlauwe B, Gentile R, Wangechi H, Mugendi D, Van Kessel C, et al. Organic and mineral input management to enhance crop productivity in Central Kenya. Agron J. (2009) 101:1266-75. doi: 10.2134/agronj2008.0188x

14. Yeboah E, Ameyaw-Ampadu R, Ansah-Amprofi F. Prioritizing Integrated Soil Fertility Management for Increased Agricultural Productivity in Ghana. Ghana Soil Health Consortium Policy Brief No. 001 (2016). p. 4.

15. Brempong MB, Opoku A, Ewusi-Mensah N, Abaidoo RC. Evaluating added benefits from combined cattle manure and fertilizer application in a maize cropping system. J Environ Sci Eng B. (2017) 6:3440. doi: 10.17265/2162-5263/2017.01.004

16. Opoku A. Sustainability of Crop Residues and Manure Management in Smallholder Cereal-Legume-Livestock Systems in the Savannas of West Africa (Ph.D. Dissertation). Kumasi: Kwame Nkrumah University of Science and Technology (2011).

17. Vanlauwe B, Sanginga N. The multiple roles of organic resources in implementing integrated soil fertility management strategies. In: Delve RJ, Probert ME, editors. Modelling Nutrient Management in Tropical Cropping Systems. Canberra, ACT: Australian Centre for International Agricultural Research (ACIAR); Centro Internacional de Agricultura Tropical (CIAT). (2004). p. 12-4.

18. Scotti R, Bonanomi G, Scelza R, Zoina A, Rao MA. Organic amendments as sustainable tool to recovery fertility in intensive agricultural systems. 
J Soil Sci Plant Nutr. (2015) 15:333-52. doi: 10.4067/S0718-95162015005 000031

19. Vanlauwe B, Wendt J, and Diels J. Combined application of organic matter and fertilizer. In: Tian G, Ishida F, Keating JDH, editors. Sustaining Soil Fertility in West Africa. SSSA Special Publication no. 58, Vol. 9. Madison, WI: Soil Science Society of America (2001). p. 247-79.

20. Crews TE, Peoples MB Can the synchrony of nitrogen supply and crop demand be improved in legume and fertilizerbased agroecosystems? A review. Nutri Cycl Agroecosyst. (2005) 72:101-20. doi: 10.1007/s10705-004-6480-1

21. Kuzyakov Y, Friedel JK, Stahr K. Review of mechanisms and quantification of priming effects. Soil Biol Biochem. (2000) 32:1485-98. doi: 10.1016/S0038-0717(00)00084-5

22. Kuzyakov Y. Priming effects: interactions between living and dead organic matter. Soil Biol Biochem. (2010) 42:136371. doi: 10.1016/j.soilbio.2010.04.003

23. Vanlauwe B, Aihou K, Aman S, Iwuafor ENO, Tossah BK, Diels J, et al. Maize yield as affected by organic inputs and urea in the West African moist savannah. Agron J. (2001) 93:1191-9. doi: 10.2134/agronj2001. 1191

24. Sanginga N, Woomer PL, editors. Integrated Soil Fertility Management in Africa: Principles, Practices, and Developmental Process. Cali: CIAT (2009). p. 263.

25. Sait G. Six Secrets to Soil Test Success, Part 1. Available online at: http:// blog.nutri-tech.com.au/six-secrets-to-soil-test-success-1/ (accessed Mar 21, 2018).

26. Sait G. Six Secrets to Soil Test Success, Part 2. Available online at: http:// blog.nutri-tech.com.au/six-secrets-to-soil-test-success-2/ (accessed Mar 21, 2018).

27. Badu M. Evaluation of Interactive Effects from Combined Cattle Manure and Mineral Fertilizer Application in Sole Maize Cropping System (Master's Thesis). Kumasi: Kwame Nkrumah University of Science and Technology (2014). p. 133.

28. FAO/UNESCO. World Reference Base for Soil Resources. World Soil Resources Report 84, Food and Agriculture Organization of the United Nations, Rome (1998)

29. Landon JR. Booker Tropical Soil Manual: A Handbook for Soil Survey and Agricultural Land Evaluation in the Tropics and Subtropics. London: Routledge (2014). p. 530.

30. Essel B, Abaidoo RC, Opoku A, Ewusi-Mensah N. Efficacy of selected crop residues and rock phosphate in improving the quality of cattle manure. Commun Soil Science Plant Anal. (2021) 1-11. doi: 10.1080/00103624.2020.1862151

31. DeWilligen P. An Analysis of the Calculation of Leaching and Denitrification Losses as Practised in the NUTMON Approach (Rapport). Plant Research International (2000). p. 18.

32. Motsara MR, Roy RN. Guide to Laboratory Establishment for Plant Nutrient Analysis. Rome: Food and Agriculture Organization of the United Nations. FAO Fertilizer and Plant Nutrition Bulletin No. 19. (2008) p. 204.

33. GenStat. GenStat Release 12.1 (PC/Windows Vista), GenStat Procedure Library Release PL20.1. VSN International Ltd. (2009).

34. SAS Institute. JMP Pro Software Release 13.0.0. Cary, NC: SAS Institute, Inc. (2016).

35. Li WQ, Liu XJ, Khan MA, Gul B. Relationship between soil characteristics and halophytic vegetation in coastal region of North China. Pak J Bot. (2008) 40, 1081-90.

36. Golabi MH, Denney MJ, Iyekar C. Use of composted organic wastes as alternative to synthetic fertilizers for enhancing crop productivity and agricultural sustainability on the tropical island of Guam. In: Proceedings of the 13th International Soil Conservation Organisation Conference 2004. Vol. 234. Brisbane (2004) p. 1-6.

37. Fening JO, Ewusi-Mensah N, Safo EY. Short-term effects of cattle manure compost and NPK application on maize grain yield and soil chemical and physical properties. Agric Sci Res J. (2011) 1:69-83.

38. Kombiok JM, Sogbedji JM, Buah SSJ, Bidzakin JK. Combining organic and inorganic fertilizers for sustainable maize production under two tillage systems in the northern savanna zone of Ghana. J Sci Eng Res. (2016) 3:289-96.
39. Gentile R, Vanlauwe B, Chivenge P, Six J. Interactive effects from combining fertilizer and organic residue inputs on nitrogen transformations. Soil Biol Biochem. (2008) 40:2375-84. doi: 10.1016/j.soilbio.2008.05.018

40. Bindraban PS, Dimkpa C, Nagarajan L, Roy A, Rabbinge R. Revisiting fertilisers and fertilisation strategies for improved nutrient uptake by plants. Biol Fertil Soils. (2015) 51:897-911. doi: 10.1007/s00374-01 5-1039-7

41. Negassa W, Abera T, Friesen DK, Deressa A, Dinsa B. Evaluation of compost for maize production under farmers' conditions. In: Seventh Eastern and Southern Africa Regional Maize Conference. (2001). p. 382-6.

42. Wang F, Wang Z, Kou C, Ma Z, Zhao D. Responses of wheat yield, macroand micronutrients, and heavy metals in soil and wheat following the application of manure compost on the North China Plain. PLoS ONE. (2016) 11:e0146453. doi: 10.1371/journal.pone.0146453

43. Hadas A, Portnoy, R. Rates of decomposition in soil and release of available nitrogen from cattle manure and municipal waste composts. Compost Sci. Utiliz. (1997) 5:48-54. doi: 10.1080/1065657X.1997.10701885

44. Vanlauwe B, Bationo A, Chianu J, Giller KE, Merckx R, Mokwunye $\mathrm{U}$, et al. Integrated soil fertility management: operational definition and consequences for implementation and dissemination. Outlook Agric. (2010) 39:17-24. doi: 10.5367/000000010791169998

45. Fairhurst T, ed. Handbook for Integrated Soil Fertility Management. Nairobi: Africa Soil Health Consortium (2012), p. 156.

46. Shaviv A, Mikkelsen RL. Controlled-release fertilizers to increase efficiency of nutrient use and minimize environmental degradation-a review. Fertil Res. (1993) 35:1-12. doi: 10.1007/BF00750215

47. Chowdhury S. Nutrient Amendment and Carbon Sequestration in Soil (Dissertation). University of South Australia (2013) p. 195.

48. Liza MMJ, Islam MR, Jahiruddin, M, Hasan MM, Alam MA, Shamsuzzaman $\mathrm{SM}$, et al. Residual effects of organic manures with different levels of chemical fertilizers on rice. Life Sci J. (2014) 11:6-12.

49. Vanlauwe B, Giller KE. Popular myths around soil fertility management in sub-Saharan Africa. Agric Ecosyst Environ. (2006) 116:34-46. doi: 10.1016/j.agee.2006.03.016

50. Okalebo JR, Palm CA, Lekasi JK, Nandwa SM, Othieno CO, Waigwa M, et al. Use of organic and inorganic resources to increase maize yields in some Kenyan infertile soils: a five-year experience. In: Bationo A, editor. Managing Nutrient Cycles to Sustain Soil Fertility in Sub-Saharan Africa. Nairobi: Academy of Science Publishers (2004) p. 359-72.

51. Sharpley AN. Effect of soil properties on the kinetics of phosphorus desorption 1. Soil Sci Soc Am J. (1983) 47:4627. doi: $10.2136 /$ sssaj1983.03615995004700030013x

52. Laboski CA, Lamb JA. Changes in soil test phosphorus concentration after application of manure or fertilizer. Soil Sci Soc Am J. (2003). 67:54454. doi: $10.2136 /$ sssaj2003.5440

53. Spychaj-Fabisiak E, Długosz J, Zamorski R. The effect of the phosphorus dosage and incubation time on the process of retarding available phosphorus forms in a sandy soil. Pol J Soil Sci. 38:23-30 (2005).

54. Opala PA, Okalebo JR, Othieno CO. Effects of organic and inorganic materials on soil acidity and phosphorus availability in a soil incubation study. ISRN Agron. (2012) 2012:597216. doi: 10.5402/2012/597216

55. Roem WJ, Berendse F. Soil acidity and nutrient supply ratio as possible factors determining changes in plant species diversity in grassland and heathland communities. Biol Conserv. (2000) 92:151-61. doi: 10.1016/S0006-3207(99)00049-X

Conflict of Interest: The authors declare that the research was conducted in the absence of any commercial or financial relationships that could be construed as a potential conflict of interest.

Copyright $(02021$ Essel, Abaidoo, Opoku and Ewusi-Mensah. This is an open-access article distributed under the terms of the Creative Commons Attribution License (CC $B Y)$. The use, distribution or reproduction in other forums is permitted, provided the original author(s) and the copyright owner(s) are credited and that the original publication in this journal is cited, in accordance with accepted academic practice. No use, distribution or reproduction is permitted which does not comply with these terms. 